\title{
Alternatīvā vēsture: Eiropas un Amerikas Savienoto Valstu jauno laiku vēstures piemērs
}

\section{Alternative History: Case of Modern History of Europe and the United States of America}

\author{
Lilita Zemīte, Dr. hist. \\ Latvijas Universitātes Vēstures un filozofijas fakultātes \\ Vēstures un arheoloğijas nodalias asociētā profesore \\ Aspazijas bulvāris 5, Rīga, LV-1050 \\ E-pasts: lilita.zemite@lu.Iv
}

\begin{abstract}
Alternatīvā vēsture pastāv ilgāk nekā simts gadu. Pēdējo divdesmit gadu laikā tā ne tikai ir kḷuvusi īpaši populāra vēsturnieku aprindās, bet var tikt uzskatīta par specifisku vēstures pētniecības nozari. Pamatā tiek analizēta alternatīvās vēstures attīstības gaita, alternatīvās vēstures dažādās izpratnes un paveidi, kā arī alternatīvās vēstures jēga, būtība un pielietojamība vēstures pētniecībā. Galvenā uzmanība rakstā veltīta virtuālajai (counterfactual) vēsturei kā vēstures pētniecības metodei un tās izmantošanas iespējām vēsturnieku darbā.
\end{abstract}

Atslēgvārdi: alternatīvā vēsture, virtuālā vēsture, faktiskā vēsture, cēlonība, vēstures fakts, jauno laiku vēsture.

Alternative history exists for a longer period than one hundred years. During the last twenty years, it has become very popular in cycles of historians, and, moreover, is considered as a particular branch of the historical research. The article touches upon development of alternative history, different approaches and forms of alternative history, as well as its sense and essence of alternative history and counterfactual history as a useful tool in scholarship of history. Counterfactual history as a method occupies an important role in the article.

Keywords: alternative history, virtual history, actual history, causation, historical fact, modern history.

Daļai akadēmisko aprindu vēsturnieku attieksme pret alternatīvo vēsturi ir visai skeptiska, jo nereti tā tiek izprasta kā izklaidējoša un viegla prāta rotalı par nekad nebijušu pagātni, ar ko nodarboties patiesībā ir bezjēdzīgi, tāpēc tā nevar būt profesionālu vēsturnieku uzmanības vērta un tāpēc alternatīvās vēstures pētījumiem nav vietas akadēmiskos izdevumos. Savukārt publiskajā telpā laiku pa laikam izskan 
apgalvojums, ka vēsturē nav pieņemts jautāt un tāpēc nedrīkst jautāt, "kas būtu bijis, ja būtu bijis?". Abi minētie priekšstati ir maldīgi. Alternatīvā vēsture tieši šādu jautājumu uzdod, un ir nepārprotami jāuzsver, ka tai ir jēga un tās būtība un mērkis nav rakstīt par nekad nebijušu pagātni. Alternatīvā vēsture, kas mūsdienās jau ir kḷuvusi par stabilu vēstures disciplīnu, iespējamo citas vēstures attīstības gaitas iztirzāšanu izmanto tikai kā formu vai metodi, lai aktualizētu kādu vēstures faktu, notikumu vai procesu un piedāvātu, iespējams, atšḳirīgu vai padziḷinātu vēstures interpretāciju un izpratni vai lai apstiprinātu jau zināmo. Viens no redzamākajiem alternatīiās vēstures pētniekiem un aizstāvjiem, pazīstamais mūsdienu britu vēsturnieks Neils Fērgusons (Niall Ferguson), ir spiests atzīt, ka alternatīvā vēsture joprojām nereti tiek uztverta kā jokaina nodarbošanās tāpēc, ka to diskreditē daudzās zemas kvalitātes, smieklīgas publikācijas, kuras pretendē būt par alternatīvās vēstures pētījumiem $^{1}$ un kurām tik tiešām nav vietas akadēmiskos izdevumos. Tātad alternatīvajai vēsturei ir sava "iekšējā" kritika un analīze, tā arī balstās uz vēstures teoriju, pie tam alternatīiās vēstures darbos pārsvarā tiek izmantotas tās pašas pētniecības metodes, kuras lieto vēsturē kopumā, un, lai arī alternatīvās vēstures darbiem piemìt savas īpatnības, kopumā tomēr var apgalvot, ka alternatīvā vēsture visai maz atškiras no "īstās" jeb faktiskās (actual) vēstures, kā to labpatīk dēvēt alternatīvās vēstures pārstāvjiem. ${ }^{2}$ Var apgalvot pat vēl vairāk visai izplatīts un argumentēts ir atzinums, ka jebkurš vēsturnieks, kurš savā darbā ne tikai fiksē faktus, bet arī tos skaidro un interpretē, pēc būtības raksta alternatīvo jeb virtuālo vēsturi, pat ja pats to neapzinās. ${ }^{3}$ Hārvarda Universitātes profesors Kāss Roberts Sansteins (Cass Robert Sunstein) norāda, ka vēstures interpretācijas ir alternatīvās vēstures formas ${ }^{4}$ tāpēc, ka vēstures un alternatīvās vēstures veidotās pagātnes ainas kopīgā iezīme ir tās nepilnīgums. ${ }^{5}$ Viens no redzamākajiem mūsdienu igauṇu vēsturniekiem, Mareks Tamms (Marek Tamm), intervijā žurnālam "Ir" atzīst, ka vēsturnieki tagadnē rada pagātni un šādā veidā to nemitīgi pārveido, ${ }^{6}$ tāpēc "akadēmiskas zināšanas ir nepilnigas, tās nekad nav pabeigtas, tās ir, iespējams, nepareizas". ${ }^{7}$

Vēstures ainas nepilnīgumu alternatīvās vēstures interpreti uzskata par būtisku reālās vēstures un arī nereālās fikcijas pazīmi, jo abos naratīvos vēsturnieki pagātni rekonstruē, vēstures faktu, detaḷu, personu rīcības motīvu vai citu pagātni veidojošu elementu trūkumu aizpildot ar interpretāciju, skaidrojumu vai pieņēmumu un tā patiesībā radot kontrolētu fikciju un maldīgu priekšstatu par pagātni. Neviens vēsturnieks nekad nespēj pārzināt un izzināt visus vēstures faktus kaut vai avotu trūkuma dēl, lai spētu veidot pilnīgu un reālu vēstures ainu. Tāpēc vēsture un alternatīvā vēsture būtībā nodarbojas ar līdzīgām lietām: vēsturnieki raksta savu stāstu par to, kas, iespējams, notika, bet alternatīvā vēsture fokusējas ne tik daudz uz to, kas notika, bet uz to, kas varēja notikt, bet nenotika. ${ }^{8}$ Tātad iespējamība ir vēstures un alternatīvās vēstures kopīga iezīme. Kā norāda N. Fērgusons, iespējamības pakāpe ir gandrīz vai būtiskākais alternatīvās vēstures kvalitātes kritērijs, jo tikai augstas ticamības jautājums "kas būtu bijis, ja..." var nodrošināt tikpat iespējamu atbildi par to, kas varēja notikt, bet pretējā gadījumā alternatīvā vēsture pati sevi diskreditē. ${ }^{9}$ Nozīmīgākā abu vēstures naratīvu atškiirība ir tā, ka vēsture cenšas stāstīt un pretendēt uz "patiesu stāstu”, savukārt alternatīvās vēstures pārstāvji apgalvo, ka "patiesais stāsts" tikai tāpēc vien, ka tas realizējās, vēl nenozīmē, ka tā bija vienīgā un tāpēc ticamākā vēstures attīstības iespēja. Tāpēc alternatīvās vēstures pētnieki uzskata, ka ticamība, uz kuru kā savu pretendē vēsturnieki, ir ne tikai vēstures, bet arī alternatīvās vēstures pazīme. ${ }^{10}$ 
Par kopīgo un atšķirīgo vēstures un alternatīvās vēstures specifikā ir teoretizējuši daudzi pētnieki, tomēr jānorāda, ka akadēmiskie vēsturnieki lielāko uzmanību velta vienam alternatīvās vēstures virzienam, ko apzīmē ar visai grūti tulkojamu nosaukumu counterfactual history. To var dēvēt arī par virtuālo vēsturi, tā noškikirot to ne tikai no "īstās" jeb "aktuālās" vēstures, bet arī no vēstures fikcijas (dailliteratūras) un zinātniskās fantastikas, kas arī ir alternatīvās vēstures paveidi. Lai gan virtuālā vēsture pēc savas būtības ir fikcija, tā tomēr, kā norāda jēdziens counterfactual, balstās uz reāliem vēstures faktiem, turklāt arī škietami maznozīmīgiem, sekundāriem un tādiem, kas neietilpst vai arī ir pretēji vispārpieņemtam vēstures vēstījumam vai koncepcijai, pie tam counterfactual vēsturi raksta tikai par reālām vēstures personībām. Viena no svarīgākajām alternatīvās vēstures iezīmēm un vienlaicīgi arī tās nozìme un jēga ir vēstures procesa cēloṇu identificēšana, kas ir cieši saistìta ar jau pieminēto alternatīvās vēstures pretenziju uz ticamību un ar faktu nozīmi vēstures pētniecībā. Ja faktiskās vēstures pētnieki pieņem un pierāda, ka notikums vai process $\mathrm{B}$ izriet no cēloṇa $\mathrm{A}$ un ir tā sekas, tad faktiski reizē tiek apgalvots: ja nav cēloṇa A, sekas B, iespējams, nesekotu. Tātad cēlonību var definēt kā divu vai vairāku faktu savstarpēju iespējamu atkarību, kas savukārt ir alternatīvās jeb counterfactual vēstures pamatā. Tāpēc cēlonssakarību kuedes noskaidrošana pēc būtības ir alternatīvā vēsture, ja tiek atzìts, ka cēlonis ir atškirīības veidotājs un atrodas noteiktas vēstures attīstības gaitas pamatā. Ja faktiskās vēstures pētnieki apstājas pie konstatācijas, ka fakts A ietekmē sekas B, tad virtuālās vēstures pētnieki iet tikai soli tālāk pa to pašu cel̦u, apgalvojot: ja nebūtu cēloṇa A un tāpēc, iespējams, nebūtu arī seku B, tad to vietā, iespējams, realizētos cita ticama iespēja C. Iespējamo seku C identificēšana arī ir viena no virtuālās vēstures atšḳirībām cēloṇsakarību ķēdes meklējumos, taču ne vienīgā.

Nereti vēsturnieki ir neizpratnē par alternatīvās vēstures jēgu un nozīmi, pamatoti jautājot, ko tā mums reāli dod un vai šì pētniecības virziena pārzināšanas vienīgais iemesls ir tikai tā pastāvēšana. Atbilde ir saistīta tieši ar cēloņsakarību ķēdes meklējumiem. Alternatīvās vēstures prāta eksperimenti, kā tos nodēvējis vēsturnieks Aleksandrs Mārs (Alexander Maar), pēc daudzu alternatīvās vēstures pētnieku domām, palīdz vēsturniekiem izsvērt un arī pārvērtēt vēstures notikumu cēloṇu nozīmi, paskatīties uz vēsturi citā gaismā vai no cita skatpunkta. Vēstures notikumu cēloṇu identificēšana ir viens no grūtākajiem vēsturnieka uzdevumiem, jo tieši šajā darba posmā visvieglāk ir iespējama alošanās, saskatot nepatiesos jeb neīstos notikumu cēloṇus, kam seko škība analīze, kā rezultātā rodas virtuālā vēsture jeb tas, kā patiesībā nemaz nav bijis. Kā teicis britu vēsturnieks Normens Deiviss (Norman $D a$ vies), tieši lielie vēstures notikumi nereti ir pamats vēsturnieku maldiem, skaidrojot to izcelšanās iemeslus. ${ }^{11}$ Viņš raksta:

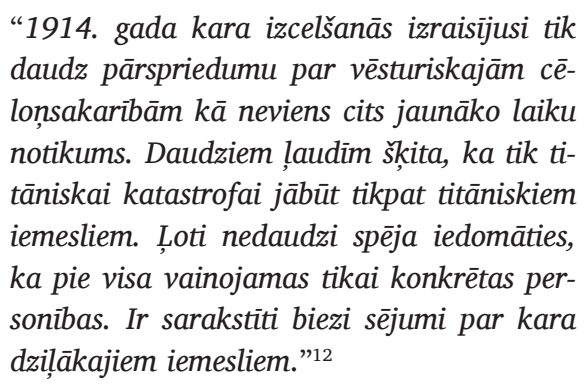

Pirmā pasaules kara izcelšanās ir tikpat populāra izpētes tēma arī alternatīvās vēstures pētījumos, taču analīze šajos darbos ir veidota no cita skatpunkta. Alternatīvās vēstures pētnieki nevis mēgina rast atbildi uz jautājumu, kāpēc karš izcēlās, vai meklēt kara izcelšanās cēloṇus, bet gan fokusējas uz iespējām un iemesliem, kas karu 
varēja novērst, un cenšas izprast, kāpēc nerealizējās iespējas saglabāt mieru? Ja vēsturnieki interpretē kara izcelšanās cēloṇus, balstoties uz zināšanām, ka tiešām karš izcēlās, tad viṇi lielākā vai mazākā mērā virzās jau zināmā rezultāta virzienā un, iespējams, neapzināti dažādus pirmskara situāciju veidojošos elementus nereti maldīgi definē kā kara iemeslus.

Turpretī virtuālās vēstures pētniekiem, piedāvājot alternatīvu notikumu norisi, šādu priekšrocību - uzzināt to, kā vēsture attīstīsies viṇu piedāvātajā variantā, - nav. Itāḷu vēsturnieks Franko Kardīni (Franco Cardini) norāda, ka tāpēc alternatīvās vēstures analītikim ir jāspēj skaidrot ne tikai reālo notikumu k,ēdi, ${ }^{13}$ bet arī to, kas tieši neḷāva vēsturei iet citu ceḷu. Tāpēc šādi alternatīvās vēstures piedāvātie domu eksperimenti liek vēsturniekam iedziļināties pētāmajā laikmetā, domāt tālaika personu vietā, un tas nereti sagādā vēsturniekam informāciju, ko viṇš, iespējams, neatklātu citā veidā ar citiem paṇēmieniem. Alternatīvās vēstures sniegtās zināšanas ḷauj pētniekam pārvērtēt notikumu cēloṇu nozīmi un svaru. Var apgalvot, ka alternatīvās vēstures pētniekam ir jābūt ìpaši profesionālam un zinošam pētāmā laikmeta detaḷās, kā arī to, ka alternatīvās vēstures paņēmieni ir nozīmīgs rīks jebkura vēsturnieka rokās. Vairāki alternatīvās vēstures pētnieki norāda, ka tieši cēloṇu izsvēršana ir visbūtiskākais alternatīvās vēstures ieguldījums vēstures pētniecībā. ${ }^{14}$

Atgriežoties pie Pirmā pasaules kara daudzajām alternatīvām, būtu nepieciešams aplūkot tikai dažas no tām. G̦entes Universitātes emeritētais profesors Rauls Šarls van Kanegems (Raoul Charles van Caenegam, 1927-2018) esejā "Alternatīvā vēsture un Pirmais pasaules karš”, izskatot iespējas, kas varēja kara izcelšanos novērst, fokusējas gan uz karā iesaistīto valstu zināmajiem, nevis interpretētajiem mērḳiem, gan arī analizē augstāko amatpersonu pienemtos lēmumus un to, kā šie lēmumi iespaidoja pirmskara situācijas attīstību. Autors secina, ka pirmskara politiskie mērḳi nebija nepārvarami šķēršlı sarunās - izṇemot, iespējams, visai bezkaunīgo, bet ne bīstamo Lielbritānijas vēlmi turpmāk dominēt Eiropas kontinentā, taču arī tās realizāciju varēja ievirzīt citā gultnē bez kara izraisīšanas, ja Eiropas mieru mīlošie līderi, tādi kā Ungārijas premjerministrs grāfs Ištvāns Tisa (István Tisza de Borosjenő et Szeged, 1861-1918) Budapeštā, lords Morlejs (John Morley, $1^{\text {st }}$ Viscount Morley of Blackburn; 1838-1923) Londonā, Vācijas kanclers Teobalds fon Betmans-Holvegs (Theobald von BethmannHollweg, 1856-1921) Berlīnē, Francijas premjerministrs Renē Vivjeni (René Viviani, 1863-1925) Parīzē un citi, kas Eiropā bija vairākumā, būtu iznākuši politiskās skatuves priekšplānā un ar enerğisku rīcību būtu nomākuši kareivīgo un aktīvo mazākumu un tā pārstāvjus Vinstonu Čērčilu (Winston Churchill, 1874-1965) Londonā un grāfu Leopoldu fon Bertoldu (Leopold von Berthold, 1863-1942) Vīnē. ${ }^{15}$ Piemēram, analizējot grāfa I. Tisas politiskos uzskatus un viņa darbību pirmskara mēnešos, skaidri iezīmējas viṇa centieni un arī potenciālās spējas novērst kara izcelšanos starp Austroungāriju un Serbiju - l,oti iespējams, tas apstādinātu notikumu ķēdi, jau pašā sākumā abu valstu attiecību skaidrošanai sasaucot starptautisku konferenci, kurā I. Tisa būtu bijis piemērots vadītājs. ${ }^{16}$ Apgalvojot, ka bija iespējams karu novērst, ja aktīvi rīkotos citas reālas vēsturiskās personas, autors patiesībā, kā var secināt, vēlas pateikt, ka šì kara cēloṇi vēsturniekiem ir jāpārvērtē vai vismaz uzmanīgi jāizsver, jo R. Š. van Kanegems uzskata, ka viņa piedāvātais vēstures virzības scenārijs būtu bijis gan l̦oti iespējams, gan arī ticams. Arī britu vēsturnieks N. Deiviss, tāpat kā lielākā daḷa prominento Rietumu vēsturnieku, patiesībā ir pievērsies alternatīvajai vēsturei, 
piedāvājot četras iespējas, kā varēja risināt pirmskara krīzi Eiropā pēc Austroungārijas erchercoga Franča Ferdinanda (Franz Ferdinand) nogalināšanas atentātā. Trijās no N. Deivisa piedāvātajām un nerealizētajām iespējām karu varēja nepiel̦aut starpvalstu sarunu ceḷā, vai arī karu lokalizēt Balkānos, ko vēlējās daudzi Eiropas pirmskara līderi, vai vismaz karu ierobežot Eiropas kontinentā. Un tikai ceturtā iespēja, kas arī realizējās, bija globāls karš, kuru par tādu pārvērta Lielbritānijas iesaistīšanās. ${ }^{17}$

Lielbritānijas iesaistǐšanos Pirmajā pasaules karā par kḷūdu uzskata arī britu Pirmā pasaules kara vēstures speciālists N. Fērgusons, kurš šo atziņu pauž gan savā monogrāfijā "Nožēlojamais karš", ${ }^{18}$ gan arī savā alternatīvās vēstures pētījumā - rakstā "Keizara Eiropas Savienība. Kas būtu, ja Lielbritānija "paliktu malā" 1914. gada augustā". ${ }^{19}$ N. Fērgusons uzskata, ka Lielbritānijas kara pieteikums Vācijai, kas bija britu ārpolitikas un ārlietu ministra sera Edvarda Greja (Edward Gray) politikas rezultāts, izraisīja globālu karu kontinentāla Eiropas kara vietā, kas nesa pārāk lielu postu Britu salām un radīja smagas sekas visā Eiropā. ${ }^{20}$ N. Fērgusons savā alternatīvās vēstures pētījumā interpretē situāciju, kur Lielbritānijas neitralitātes rezultāts ir Vācijas ātra uzvara Pirmajā pasaules karā. Savā alternatīvās pēckara Eiropas analīzē N. Fērgusons balstās uz pirms kara, nevis kara laikā Vācijas formulēto mērḳu interpretāciju (ko kḷūdaini mēdz darīt daḷa vēsturnieku), secinot, ka Vācijas uzvara būtu Eiropas Savienības 1914. gada variants ar Vācijas impērijas dominanci kontinentā. Karā uzvarējusī k̦eizariskā Vācija būtu alternatīva vājajām demokrātijām Vācijā un Eiropā un to radītajam varas vakuumam, kas pieḷāva fašisma, nacisma un komunisma ideologiju un režīmu uzvaras gājienu Eiropā. Eiropa uzplauktu, Lielbritānija paliktu impērija, un būtu izglābtas dzīvības miljoniem eiropiešu. ${ }^{21}$ Monogrāfijā
"Nožēlojamais karš" alternatīvās vēstures attīstības gaitas apraksts aizṇem tikai mazāko daḷu, bet lielākā daḷa monogrāfijas teksta nav alternatīvā vēsture vai vismaz tāda nešķiet. Tomēr uz N. Fērgusona darbu var paskatīties arī citādāk. Ideja, ka autors kā labāku alternatīvu Eiropai saskata Vācijas, nevis sabiedroto valstu uzvaru karā, pēc būtības ir revizionistiska attiecībā pret ilgstoši vispārpieņemto Pirmā pasaules kara vēstures konceptuālo traktējumu jeb t. s. sabiedroto vēstures versiju, kas Pirmo pasaules karu interpretē kā Labā (Good) un L̦aunā (Evil) cīṇu, kur ar L̦auno ir jāsaprot Vācija un tās pusē karojošās valstis. ${ }^{22}$ N. Fērgusons k,eizarisko Vāciju neuzskata par L,auno, jo iespējamo tās uzvaru neuztver kā Eiropas civilizācijas bojāeju. Vācija viṇa pētījumā nav ne labāka, ne sliktāka par sabiedrotajām valstīm.

Nereti par alternatīvo jeb citu vēsturi ir pieņemts arī uzskatīt asi revizionistiskus vēstures pētījumus, kuros ir atšksirīgi vērtētas nevis detaḷas vai pārvietoti akcenti, bet piedāvāta diametrāli pretēja koncepcija vispār zināmajai. N. Fērgusona darbs pilnībā atbilst šai revizionistiskajai alternatīvās vēstures izpratnei. Revizionistiskajam alternatīvās vēstures virzienam piederīgi arī Amerikas Savienotajās Valstīs 20. gadsimta 70.-80. gados ḷoti populārā tā saucamās Jaunās ekonomiskās vēstures (New Economic History) skolas pētnieki jeb kliometristi. Tās pārstāvji - vēlākais Nobela prēmijas laureāts ekonomikā (1993) Roberts Fogels (Robert Fogel, 1926-2013) un Stenlijs Engermans (Stanley Engerman) savā kopdarbā "Laiks uz krusta", izmantojot matemātiskās metodes, precīzā dažādu faktu un skaitlıu uzskaitē, kas raksturoja 19. gadsimta vidus Amerikas Savienotās Valstis, secināja, ka plantāciju verdzība ASV Dienvidu štatos ir bijusi ekonomiski izdevīga un produktīva. ${ }^{23}$ Protams, šāda konstatācija nepavisam neatbilda ASV dominējošiem liberālajiem politiskajiem 
uzskatiem grāmatas izdošanas laikā. Šo kvantitatīvo alternatīvās vēstures argumentāciju R. Fogels izmantoja arī savos vēlākajos pētījumos, kas bija veltīti 19. gadsimta ASV dzelzceḷu celtniecības un to nozìmes izvērtēšanai valsts ekonomikā. Līdz tam ASV vēstures zinātnē dominēja uzskats, ka dzelzceḷš bija vitāli nepieciešams un ASV industrializāciju veicinošs faktors. R. Fogels savā darbā bez jau minētās kvantitatīvās metodes izmantoja arī citu alternatīvās vēstures paṇēmienu: lai pamatotu viedokli par kāda elementa nozīmi vēsturē, šì elementa eksistence pētījumā apzināti tiek ignorēta. R. Fogels savu alternatīvo ekonomiskās attīstības vēsturi par 19. gadsimta otro pusi rakstijja bez dzelzceḷa komponenta un nonāca pie secinājuma, ka arī šādā situācijā, t. i., bez dzelzceḷa, ASV iekšzemes kopprodukts būtu bijis tikai nedaudz mazāks, nekā tas reāli bija 1890. gadā. ${ }^{24}$ Autora uzskatu, ka dzelzceḷa loma ASV ekonomiskajā vēsturē ir pārspīlēta, ar citām pētniecības metodēm būtu grūti izsvērt.

Cits amerikāņu vēsturnieks Džeimss Akstels (James Axtell) šo alternatīvās vēstures pētniecības metodi ir izmantojis, lai panāktu pretējo, t. i., lai pierādītu nepamatoti vienkāršoti un vienpusēji novērtēta faktora - ASV pamatiedzīvotāju jeb indiānu vietu un lomu ASV vēsturē. Pēc Dž. Akstela domām, ASV historiogrāfijā pamatiedzīvotāji ilgstoši ir tikuši pētīti vai nu kā pašpietiekams fenomens, ar to saprotot indiānu kultūru un etnogrāfiju, vai arī tiem ir tikusi ierādīta upuru loma, kuri neko nedarīja, vai arī varoṇu loma, kuri nemitīgi pretojās. Lai mainītu šo pieeju, autors ir veicis alternatīvās vēstures pētijumu, rakstot ASV koloniālā perioda vēsturi bez indiāṇu klātbūtnes. Tas, ka amerikāṇu angḷu valodā nebūtu neviena no pamatiedzīvotāju valodām aizgūta vārda, iespējams, arī internacionālisma “O. K.”, ir saprotams, taču autors par būtiskākajiem sava darba secinājumiem uzskata iespējami atškiirīgās kontinenta kolonizācijas procesa iezīmes. Eiropieši, nezinot par zeltu Dienvidamerikā, ko viṇi redzēja pie indiāṇiem, iespējams, turp tā netiektos, savukārt franču kolonistus, iespējams, mazāk interesētu Kanāda, ja tur nebūtu kažokādu zvēru mednieku un ādu pārdevēju, jo tieši šīs tirdzniecības saites bija franču kolonizācijas dzinulis šajā teritorijā. Angḷi un citi Eiropas disidenti Amerikā ierastos neatkarīgi no pamatiedzīvotāju klātbūtnes, taču, iespējams, nedzīvotu kompakti, lai aizsargātos, un arī ASV vēsturē nozīmīgākās koloniālā perioda "robežas", kas saistās tieši ar indiāṇu klātbūtni, proti, Aleganu kalnu, nebūtu, tāpēc kolonisti ātrāk izklīstu pa kontinentu, un, iespējams, lielo ASV Austrumu krasta pilsētu, kuras veidojās kā pret indiāṇiem nocietināti forti, nebūtu. Kolonistiem ilgi nebūtu zināmas Amerikas pamatiedzīvotāju izmantotās lauksaimniecības kultūras, un tā ne tikai aizkavētos ASV lauksaimniecības attīstība, bet arī Eiropa ilgi neiepazītu Amerikas ražīgās kultūras, kuru patēriņš kvalitatīvi mainīja eiropiešu ēšanas paradumus, kas bija pamatā straujam jauno laiku Eiropas iedzīvotāju skaita pieaugumam. ${ }^{25}$ Dž. Akstels min vēl daudzus piemērus, tomēr lietderīgi akcentēt būtu tikai vienu. ASV historiogrāfija visai vienprātīgi atzīst, ka viens no iemesliem, kādēl Amerikas kolonisti uzvarēja Neatkarības karā, bija kolonistu izmantotā partizānu kara taktika. To kolonisti bija apguvuši cīnās ar indiāniem, tie bija arī pārṇēmuši vinu cīṇas metodes, kas bija teicami piemērotas Amerikas dabas un klimatiskajām īpatnībām. Bez šīm iemaṇām un kara taktikas Amerikas kolonistu uzvaru ASV Neatkarības karā ir pamats apšaubìt. ${ }^{26}$ Daudzi Dž. Akstela apgalvojumi ir diskutabli, taču svarīgi ir tas, ka autors piedāvā izvērtēt un mainìt gan attieksmi, gan pētniecību par pamatiedzīvotāju vēsturi. Viṇš uzskata, ka indiāṇu vēsturi nepieciešams uztvert ne tikai kā pašpietiekamu etnogrāfisku fenomenu, bet arī kā ASV vēstures 
integrālu dalı, kas caurvij un ietekmē ASV vēsturi kopumā. N. Fērgusons gan visai kritiski vērtē šāda veida paṇēmienu izmantošanu alternatīiās vēstures darbos, jo tā pamatā nav alternatīvās vēstures pētniecības pamatnosacījuma - ticamas iespējamības, taču, ja iztēle kalpo tikai kā palīglīdzeklis, tad, vinaprāt, tā ir pieḷaujama. ${ }^{27}$

Ticama iespējamība kā alternatīvās vēstures nosacījums visbiežāk ir konstatējama, un tāpēc alternatīvās vēstures modeḷi tiek piedāvāti tajās pagātnes situācijās, kas bija indivīda vai cilvēku grupas lēmuma ietekmētas, kad jautājumus izlēma valstu līderi, militārpersonas vai parlamenta balsojumi ar vienas balss pārsvaru, vai arī vēstures negadījumi, kuri bija pilnīgi nejauši un tāpēc neparedzami, varēja būt cēlonis neprognozējamu notikumu k,ēdei. Modelējot iespējamo vēstures attīstības gaitu šāda tipa situācijās, alternatīvās vēstures pētījumi bīstami viegli var ieslīdēt triviālu, nepamatotu prognožu gultnē, tāpēc nopietni pētnieki balstās uz vēstures teoriju, kas ilgstoši ar šādiem jautājumiem nodarbojas. Georgs M. Reišs (George M. Reisch) savā darbā "Haoss, vēsture un naratīvs" postulē ideju, ko labprāt pieņem alternatīvās vēstures pētnieki: vēstures notikumi ir l,oti sensitīvi to variācijās, tāpēc nereti maznozīmīgas izmaiņas, ko dēvē par nejaušìbām, vēsturē it kā prognozējamā notikumu virknē var generēt dažādas variācijas, kuras izmaina visu finālu. G. M. Reišs norāda, ka pārmērīga vēstures strukturēšana un neprognozējamības noliegšana noved pie vēstures faktu ignorēšanas un lineāras vēstures uztveres, kaut gan vēstures gaita, pēc autora domām, ir ne tikai sociālu un ekonomisku spēku noteikta, bet gan multiplicētu faktoru rezultāts. ${ }^{28}$ Tātad determinētas vēstures gaitas neietekmējamas virzības apšaubīšana, uz ko atsaucas alternatīvā vēsture, nebūt nenozīmē cēloṇsakarību noliegšanu, bet gan cēlonības komplicētības aizstāvēšanu tās vienkāršošanas vietā.
Alternatīvā vēsture neḷauj vēsturniekam pazaudēt intimitāti ar vēstures faktu, ko, pēc N. Fērgusona redzējuma, patiesībā piedāvā vēstures deterministi. ${ }^{29}$

Analizējot personību ietekmi vēsturē, gandrīz visi alternatīvās vēstures pētnieki balstās uz klasiḳa Jesajas Berlina atzinumiem par cilvēkam piemītošo "brīvo gribu" - saskaṇā ar to indivīdi izvēles izdara brīvās gribas, nevis nolemtības rezultātā, tā veidojot vēsturi. ${ }^{30}$ Tāpēc alternatīvās vēstures pārstāvji apšauba deterministu postulēto apziņu, ka tā vēsture, kas ir īstenojusies, bija vienīgais cel̦š, kurš varēja realizēties un bija iespējams. Pat vēl vairāk, daži autori uzskata, ka ir gadijjumi, kad virtuālā vēsture bija drīzāk iespējama un tāpēc tuvāka vēsturiskajai patiesībai, nevis tā, kas realizējās, jo scenārijs, kas īstenojās, ne vienmēr ir bijis tas iespējamākais. ${ }^{31}$ Tāpēc jautājumam "kas varēja notikt, ja ..?" ir tiesības pastāvēt. Vēsturniekam, izskatot alternatīvās iespējas, ir jāpārzina ne tikai viens sava pētījuma segments, bet jāredz alternatīva plašā kontekstā, ja nepieciešams, jānovērtē arī starptautiskās situācijas ietekme. Alternatīvās vēstures jautājumu nav jēgas izvirzìt tikai tāpēc vien, ka tas škiet interesants, ne arī aizvietot vienu vēstures personu ar citu tikai tāpat vien. N. Fērgusons, kurš ir l,oti norūpējies par alternatīvās vēstures pētījumu augstajiem standartiem, šādu pārāk brīvu alternatīvu veidošanu nodēvējis par vēlmju domāšanu, kad alternatīvo modeḷu autori abstrahējas no vēsturiskās realitātes un veido scenāriju, kādu to labprāt redzētu un vēlētos iztēloties.

Piemēram, ja Vācijas k̦eizara Vilhelma II (Wilhelm II) tēvs Frīdrihs III (Frederick III) būtu nodzīvojis ilgāk, tad karš nebūtu izcēlies, ${ }^{32}$ vai ja Kolumbs, avarējot kug̣im, nebūtu atklājis Ameriku, tad Eiropas attīstība būtu citāda; vai ja Džons F. Kenedijs (John Kennedy, 1917-1963) nebūtu nogalināts, ASV neiesaistītos Vjetnamas kara eskalācijā, taču Frīdrihs III nomira, Lielo 
ǵeogrāfisko atklājumu laikmetā Amerika jebkurā gadījumā būtu atklāta, bet Dž. Kenedija iespējamā ārpolitika, kā norāda Jeilas Universitātes pētniece Diāna Kunca (Diana Kunz), ir jāmodelē saskaṇā ne tikai ar viņa politiskajiem uzskatiem un agrāko darbību, bet arī ar reālo starptautisko situāciju, kurā viņš neizdzīvoja, bet, kurā nonākot, vinšs, pēc D. Kuncas domām, visticamāk, rīkotos tāpat, kā to darīja nākamais prezidents Lindons Džonsons (Lyndon Johnson, 1908-1973). ${ }^{33}$ Šie piemēri rāda gan to, ka personību, lai arī tai piemīt brīvā griba, var ierobežot vēsturiskā realitāte, gan arī to, ka vēstures virzība, ejot pa citu ceḷu, var nonākt pie jau zināma rezultāta.

Uzdot labu alternatīvās vēstures jautājumu, manuprāt, ir izdevies amerikāṇu vēsturniekam Arturam Šlēzingeram (Arthur Schlesinger, 1917-2007). Viņš aktualizē reālu vēstures notikumu, kad 1931. gadā N̦ujorkā V. Čērčilu notrieca mašĩna, bet viņš, par brīnumu, maz cieta. Tāpēc A. Šlēzingers pamatoti piel̦auj iespēju, ka 1940. gadā Lielbritānijas valdība, visticamāk, Edvarda Halifaksa (Edward Wood, Viscount Halifax, 1881-1959) vadībā, nebūtu mobilizējusi nāciju pretestībai Vācijai. ${ }^{34}$ Autors tā var apgalvot, jo E. Halifakss bija ārlietu ministrs V. Čērčila valdībā un savus samiernieciskos uzskatus pauda atklāti un nepārprotami, tātad viņš konkrētajā vēstures situācijā nav jāiztēlojas, balstoties uz varbūtību. Šis piemērs savukārt ilustrē situāciju, kā personība vēsturisko realitāti spēj ietekmēt.

Šķiet, ka Latvijā visbiežāk uzdotais alternatīvās vēstures jautājums ir par Kārḷa Ulmaņa rīcību 1940. gadā. Gan vēsturnieki, gan sabiedrība ir visai vienprātīga atbildē, ka nekāda cita rīcība okupāciju nenovērstu, jo to liek secināt situācijas patiesa izpratne, taču varbūt būtu vēlams K. Ulmaņa vietā saskatìt citu alternatīvu personību Latvijas 1940. gada politiskajā vidē vai arī paanalizēt iespējamo Saeimas sastāvu, lai pamatotu cita rīcības modeḷa iespējamību.
Šis Latvijas vēstures piemērs parāda vēl vienu alternatīvās vēstures iezīmi, proti, kad citu vēstures attīstības gaitu pag̣ēr sabiedrībai traǵiski vēstures notikumi un ir stipra vēlme, lai viss būtu bijis citādi, meklējot iespējamās kḷūdas vai liktenīgos lēmumus pagātnē. Šādu vēlmi spilgti izgaismo un uzrāda, šḳiet, ASV vēsturē vislielākais alternatīvās vēstures modeḷu daudzums, kas liek secināt, ka liela daḷa amerikāṇu sabiedrības, vismaz dienvidos, būtu vēlējusies Dienvidu uzvaru ASV pilsonu karā. Amerikāṇu vēsturnieki un sabiedrības pārstāvji - vēstures entuziasti - ir sarakstījuši nepārskatāma apjoma darbus gan par Dienvidu uzvaru karā, gan par tai sekojošās Amerikas Valstu Konfederācijas vēsturi, un rodas iespaids, ka ir visai vienprātīgi par lūzuma punktu un liktenīgo kḷūdu pilsoṇu karā uzskatīt Getisbergas kauju, kas padarīja neiespējamu atsevišķas valsts izveidi. Getisbergas kauja ir identificēta un eleganti pamatota, jo pirms tās, novērtējot Ziemeḷu smagās neveiksmes karā, prezidents Ābrahams Linkolns (Abraham Lincoln) un Konfederācijas pārstāvji jau bija vienojušies par miera sarunām, kas pēc iespējamās uzvaras pie Getisbergas būtu vēl uzlabojušas Dienvidu pozīcijas sarunās, taču pēc Dienvidu zaudējuma $\bar{A}$. Linkolns no miera sarunām atteicās vispār. Pie tam leǵendāro kauju izškīira nevis Ziemeḷu armijas pārsvars, bet gan tikai Konfederācijas armijas generāla Roberta Lī (Robert Lee) kḷūdainā pavēle, kā to ir novērtējuši gan ASV militārie vēsturnieki, gan arī atzinis R. Lī pats. ${ }^{35}$ Getisbergas kaujas alternatīvs iznākums ir l,oti ticams, un tāpēc lielais tam veltīto darbu skaits ir logisks. Iespējams, tieši tāpēc V. Čērčils dažādības pēc uzrakstīja alternatīvas alternatīvu "Kas būtu bijis, ja Lī pie Getisbergas nebūtu uzvarējis?", tā piedāvājot redzējumu it kā no alternatīvās pasaules. ${ }^{36}$ Militārpersonu lēmumi, karavadoṇu kḷūdas un alternatīvi kauju iznākumi ir īpaši populārs temats, par kuru ir izdota 
virkne rakstu krājumu, ${ }^{37}$ tā apliecinot personību nozīmīgumu vēstures griežos.

Noslēgumā jāpiemin arī alternatīvās vēstures joma: zinātniskā fantastika ar vēsturiskas daiḷliteratūras iezīmēm, kas laika posmā no 1870. gada līdz 1914. gadam bija ārkārtīgi populāra Britu salās, jo tur tika izdoti apmēram 60 darbi, kas ieguva nosaukumu: iebrukumu jeb invāziju literatūra. To autori apskatīja tuvākajā nākotnē it kā iespējamos iebrukumus Britu salās, kurus veiktu pārsvarā kontinentālās Eiropas valstis dažādās koalīcijās. Šo iespējamo koalīciju sastāvs mulsinoši veidojās tieši no tām valstīm, ar kurām darbu rakstīšanas laikā Lielbritānijai bija sliktas attiecības. Analizējot šos fantastikas darbus, Vācija Britu salās iebruka 19. gadsimta 80. gados pēc tikko notikušā Franču-prūšu kara un Vācijas un Austroungārijas militārā līguma noslēgšanas. Savukārt Francija kopā ar Krieviju un dažkārt arī Vācija tika aprakstītas kā iebrucējas Britu salās 19. gadsimta 90. gados, kad tika noslēgts Francijas un Krievijas līgums un Lielbritānijā bija bažas par iespējamo Vācijas pievienošanos koalīcijai, kas varētu tikt vērsta pret britiem. Arī studentiem bieži vien ir grūti izprast, ka Antanti, tas ir, Krievijas un Francijas līgumu, baiḷpilni un kā pret sevi vērstu uztvēra Britu salās, un līdz ar to nav viegli pamatot Lielbritānijas neskaidro ārpolitiku pirmskara Eiropā un parādīt, ka sabiedroto koalīcija nebija nolemta neizbēgamībai, bet gan bija komplicētu peripetiju rezultāts.

Tieši iebrukuma literatūra reāli palīdz to izprast, it kā iejūtoties tālaika cilvēku domāšanā un Eiropas politiskajā situācijā, tā radot izpratni par nelineāru vēstures attīstību. Pie tam arī pirmskara Lielbritānijā invāziju literatūras gaisotnē politiki sāka nopietnāk nodarboties ar Britu salu aizsardzības spēju stiprināšanu. ${ }^{38}$ Mūsdienās ASV skolās alternatīvo vēsturi nereti izmanto mācību procesā un ir pat publicēti dažādi mācību līdzekḷi ar norādēm, kā tieši praktiski alternatīvo vēsturi piemērot vēstures procesu skaidrošanā. ${ }^{39}$

Tātad var secināt, ka alternatīvā vēsture var tikt izmantota kā vēstures pētniecības rīks jeb metode, kas dod iespēju dziḷāk vai atškirīgi interpretēt vēstures procesus, izprast un izsvērt to cēloṇu nozīmību. Tà palīdz aktualizēt vēsturē nenovērtētu faktu, vēstures subjektu nozīmi, bagātina teorijas par personību lomu vēsturē, vienlaicīgi veicinot personu atbildību par pieñemtajiem lēmumiem. Tā uzrāda nozīmīgākās tēmas un nācijas svarīgākos un izškirirošākos vēstures posmus un jautājumus; savukārt revizionistiskās alternatīvās virziens veicina vēstures zinātnes attīstību, bet zinātniskā fantastika un vēstures daiḷliteratūra palīdz ne tikai iedziḷināties laikmetā, bet arī var sabiedrību brīdināt par notikumu attīstības iespējām nākotnē.

\section{ATSAUCES UN SKAIDROJUMI}

${ }^{1}$ NiAll FERguson. Introduction. In: NiAll FERguSON (ed.). Virtual History: Alternatives and Counterfactuals. New York 1999, pp. 1-90, here pp. 17-19.

${ }^{2}$ ONDREJ SLADEK. Between History and Fiction: On the Possibilities Alternative History, 2007, p. 3. Pieejams: http://saf.flu.cas.cz/fictionality2/sladek.pdf (skatīts 01.06.2019.). Šo resursu uztur Čehijas Zinātṇu akadēmijas Filozofijas institūta Analītiskās filozofijas nodaḷa (Department of Analytic Philosophy, Institute of Philosophy, CAS).

${ }^{3}$ AleXAnder MaAR. Possible uses of counterfactual thought in history. In: Principia: an International Journal of Epistemology 18, 2014, No. 1, pp. 88-113, here p. 88.

${ }^{4}$ CAss Robert Sunstein. Historical Explanations Always Involve Counterfactual History. In: Journal of Philosophy of History 2015, No. 15, p. 1.

${ }^{5}$ Ibidem. 
${ }^{6}$ Pauls Raudseps, MareK TAMm. Senās cinnas nebeidzas. In: Ir 2018, Nr. 4, 27.-30. lpp., šeit 27. lpp.

${ }^{7}$ Ibidem.

${ }^{8}$ SLADEK, Between History and Fiction, p. 3.

${ }^{9}$ FERGUSON, Introduction, p. 19.

${ }^{10}$ MAAR, Possible uses of counterfactual thought in history, p. 88.

${ }^{11}$ NORMANS DEIVISS. Eiropas vēsture. Rīga 2009, 908. lpp.

${ }^{12}$ Ibidem.

${ }^{13}$ MAAR, Possible uses of counterfactual thought in history, p. 91.

${ }^{14}$ Ibidem, p. 108.

${ }^{15}$ RaOul Charles VAN CAEnegem. Counterfactual History and the First World War. In: European Review 25, 2017, issue 3, pp. 494-501, here pp. 494-495.

${ }^{16}$ Ibidem.

${ }^{17}$ DEIVISS, Eiropas vēsture, 899.-900. lpp.

${ }^{18}$ NiAll Ferguson. The Pity of War. Explaining World War One. New York 1999.

${ }^{19}$ NiAll Ferguson. The Kaiser's European Union: What had stood asside in August 1914. In: FERGUSON, Virtual History, pp. 228-280.

${ }^{20}$ LILITA ZEMĪTE. Rietumu pasaule modernajos laikos: vēstures problēmas. Rīga 2019, 57. lpp.

${ }^{21}$ FERGUSSON, The Pity of War; FERGuson, The Kaiser's European Union.

${ }^{22}$ DeIviss, Eiropas vēsture, 64.-66. lpp

${ }^{23}$ Robert William Fogel, Stanley Lewis Engerman. Time on the Crosss: The Economics of the American Negro Slavery. Boston 1971. Sk. arī RoBERTS SAULĪTiS. Plantāciju verdzības pētniecības pirmsākumi ASV historiogrāfijā. In: Latvijas Universitātes Žurnāls. Vēsture 2017, Nr. 3, 136.-150. lpp., šeit 145.-146. lpp.

${ }^{24}$ FERGUSON, Introduction, pp. 17-18.

${ }^{25}$ JAMES AXTELL. Colonial America without the Indians: Counterfactual Reflections. In: The Journal of American History 73, 1987, No. 4, pp. 981-996.

${ }^{26}$ Ibidem.

${ }^{27}$ FERGUSON, Introduction, p. 18.

${ }^{28}$ GeORg A. REISCH. Chaos, History and Narrative. In: History and Theory 30, February 1991, No. 1 , pp. 1-20.

${ }^{29}$ FERGUSON, Introduction, p. 5.

${ }^{30}$ MAAR, Possible uses of counterfactual thought in history, p. 93. Vēsturisko determinismu Berlins kritizē esejā "Vēsturiskā neizbēgamība": JESAIJA BERLINS. Četras esejas par brīvību. Rīga 2000, 99.-147. lpp.

${ }^{31}$ RICHARD B. BERNSTEIN. Review of Niall Ferguson, ed. Virtual History: Alternatives and Counterfactuals. Pieejams: https://networks.h-net.org/node/16794/reviews/16921/bernsteinferguson-virtual-history-alternatives-and-counterfactuals (skatìts 01.06.2019.).

${ }^{32}$ FERguson, Introduction, p. 13.

${ }^{33}$ DiAnA KunZ. Camelot Continued: What if John F. Kennedy had lived. In: Ferguson, Virtual History, pp. 368-390.

${ }^{34}$ Arthur Meier Schlesinger. The Cycles of American History. Boston, New York 1999, p. 421.

35 JoHN FREDERIC FULLER. Grant and Lee. A Study in Personality and Generalship. Bloomington 1982, pp. 193-201.

${ }^{36}$ WinStON SPENCER CHURCHILL. If Lee Had Not Won the Battle of Gettysburg. Pieejams: https://winstonchurchill.org/publications/finest-hour-extras/qif-lee-had-not-won-the-battle-ofgettysburgq/ (skatīts 29.05.2019.). 
${ }^{37}$ Sk., piem.: RoBERT COWLEY (ed.). What If? The world foremost military historians imagine what might have been. New York 1999.

${ }^{38}$ Sk., piem.: Cecil DeGrotte Eby. Road to Armaggedon: the Martial Spirit in English Popular Literature, 1870-1914. Durham 1987, pp. 10-22.

${ }^{39}$ SCOTT L. RoBERTS. Using Counterfactual History to Enhance Students Historical Understanding. In: The Social Studies 102, 2011, Issue 3, pp. 117-123.

\section{SUMMARY}

This article is dedicated to alternative history, which today enjoys a particular popularity both in public space and within the circles of academic historians. The article analyses the theory and directions of alternative history, as well as the methods of research and the more frequently used concepts. It also examines different opportunities of using alternative history in research of European and Northern American modern history. The article attempts to substantiate the sense and meaning of alternative history in historical research. Counterfactual history as a form of alternative history has been accepted among academic historians is based in true facts, real historical situations, with participation of real historical personalities. Thus, the representatives of the counterfactual history suggest plausibility as a quality measure of their research. The representatives of the counterfactual history see a sense of their research in more profound evaluation and weighing the causes of historical events and processes. Thereby they offer a more comprehensive understanding of history. The counterfactual history is based upon theoretical standpoints on free will and it tends to confront historical determinism of inevitability with contingency in history. The article analyses the way how weighing of causes manifests itself in the research of origins of the First World War. According to the ideas of counterfactual history representatives, the outbreak of the First World War was not inevitable, consequently, examination of pre-war situation and the involved personalities offers several plausible alternatives to preventing or limiting the First World War. Such analysis, in its turn, dictates a re-examination of reasons behind war origins and accentuates the role of personalities - politicians and diplomats. Personalities and their role in history is one more object of research for alternative historians, because it is based on the idea about sensitivity of historical fact. A fact can be influenced by decisions of political and military leaders. The article turns to the cases of alternative history approach regarding US Civil War, Vietnam War and the role of politicians and generals in the aforementioned conflicts. For example, the battle of Gettysburg had been identified as a significant breaking point that led to Northern victory in the American Civil War, but there were several ways for North to lose it. The death of John F. Kennedy had been considered as a potential reason for Vietnam War, however, it was plausible that the outbreak of the war was actually inevitable. The article also explores the revisionist wing of alternative history, represented by adherents to New Economic History and their research devoted to industrialisation issues of the USA and Southern slavery problems. The current article also mentions science fiction as a particular direction of alternative history. For example, it describes the potential European war long before the First World War.

The author suggests that alternative history is a possible tool in historical research. 